\section{Cultivar and Growing Region Influence Return Bloom in Cranberry Uprights}

\author{
Bernadine C. Strik ${ }^{1}$ \\ Department of Horticulture, Oregon State University, Cowallis, \\ OR 97331-2911
}

Teryl R. Roper ${ }^{1}$

Department of Horticulture, University of Wisconsin, Madison, UT53706

\author{
Carolyn J. DeMoranville ${ }^{2}$ \\ Cranberry Experiment Station, University of Massachusetts, East \\ Wareham, MA 02538
}

Joan R. Davenport ${ }^{3}$

Ocean Spray Cranberries, 1 Ocean Spray Drive, Lakeville-Middleboro, MA 02349

\author{
Arthur P. Poole ${ }^{4}$ \\ Coos County Extension, 290 North Central, Coquille, OR 97423
}

Additional index words. Vaccinium macrocarpon, fruit set

\begin{abstract}
This research was undertaken to document the extent of biennial bearing in flowering uprights by American cranberry (Vaccinium macrocarpon Ait) cultivar and growing region. Seven cultivars were studied: three found in all states considered (Massachusetts, New Jersey, Wisconsin, Oregon), two common to Massachusetts and New Jersey, and two other commercially grown cultivars, one each from Wisconsin and Oregon. There were significant cultivar, region, and cultivar $\times$ region interaction effects for both percent return bloom $(\% \mathrm{RB})$ and percent return fruit $(\% \mathrm{RF})$. Percent RB ranged from $74 \%$ for 'Ben Lear' in Wisconsin to $14 \%$ for 'Howes' in New Jersey. 'Ben Lear' differed the most in \% RB among regions, from $74 \%$ in Wisconsin to $14 \%$ in Massachusetts. However, in some regions, especially in Wisconsin, many blossoms did not set viable fruit. There was no significant difference in $\% \mathrm{RB}$ among cultivars grown in Massachusetts or Oregon; however, cultivars grown in these regions did differ in $\% \mathbf{R F}$.
\end{abstract}

The American cranberry is a low-growing, trailing, woody, nondeciduous perennial plant. Flowers are borne on vertical stems called uprights. Uprights are terminated by a mixed bud, which contains the differentiated tissue that will produce new shoot growth and flowers, if present, in the spring (Eck, 1990).

Biennial bearing has long been thought to occur in cranberry uprights. Return bloom on flowering uprights (flowering in successive years) can range from $12 \%$ to $65 \%$ depending on year, bed vigor, and cultivar (Baumann and Eaton, 1986; Eaton, 1978; Roberts and Struckmeyer, 1942).

This research was undertaken to document the extent of biennial bearing in flowering cranberry uprights by cultivar and growing

Received for publication 11 Mar. 1991. The cost of publishing this paper was defrayed in part by the payment of page charges. Under postal regulations, this paper therefore must be hereby marked advertisement solely to indicate this fact.

'Assistant Professor.

${ }^{2}$ Cranberry Specialist.

${ }^{3}$ Agricultural Scientist.

${ }^{4}$ Horticultural Extension Agent. region. The extent of biennial bearing was studied in four major commercial cranberrygrowing regions: Massachusetts (MA), Wisconsin (WI), New Jersey (NJ), and Oregon (OR). Seven commercially grown cultivars were studied: 'Stevens', 'Ben Lear', and 'Crowley' in MA, WI, NJ, and OR; 'Early Black' and 'Howes' in MA and NJ; 'Searles' in WI; and 'McFarlin' in OR.

In Fall or Winter 1989/1990, six 2-m transects were randomly selected within a bed for each cultivar in each region. In MA, WI, and $\mathrm{NJ}$, uprights were tagged in the fall after harvest, before flooding beds for winter protection. In OR, beds are not flooded, as winter temperatures are not low enough to maintain an ice cover and winter injury is rare. Along each transect, at least 60 uprights that flowered in 1989 were tagged at their base using vinyl tape. Fruiting in 1989 was based on the presence of persistent pedicels, called hooks, on the upright (Fig. 1). Uprights that only had pedicels with the dried flower still attached were not tagged. In 1990, after fruit set, 50 of the tagged uprights per transect were randomly sampled to determine percent return bloom (\% RB) and percent return fruit $(\% \mathrm{RF})$ of at least one viable fruit per upright (Fig. 1). In two replicates of 'Crowley' in MA, fewer than 50 tagged uprights (34 and 37) could be sampled, and in WI, only 40 uprights could be sampled in four replicates due to death of uprights by tip worm (Dasyneura vaccinii Smith) or winter damage. In NJ, two replicates each of 'Stevens' and 'Howes' could not be located after the winter flood.

Percent RB and \% RF were tested by analysis of variance for unbalanced designs. Means were compared by a Waller test. Cultivar, region, and the cultivar $\times$ region interaction were significant $(\mathrm{P}<0.01)$ for both $\% \mathrm{RB}$ and \%RF. Regional effects could not be separated from cultural or environmental effects. Across cultivars and regions, \%RB ranged from $14 \%$ for 'Howes' in NJ to $74 \%$ for 'Ben Lear' in WI (Table 1). Baumann and Eaton (1986) found that fruiting uprights of 'Ben Lear', 'Bergman', and 'McFarlin' in British Columbia (BC) did not differ in the production of terminal flower buds. The low \% RB in general in this study is consistent with previous reports (Baumann and Eaton, 1986; Eaton, 1978; Lenhardt and Eaton, 1977; Roberts and Struckmeyer, 1942).

Flower bud initiation for the next year's crop begins in late June to early July (Eaton, 1978). He found that early removal of flowers and developing fruit of flowering uprights of 'McFarlin' resulted in an increase in floral induction; defloration on 6 June resulted in $51 \%$ RB compared to $27 \%$ in the nontreated control. Later defloration increasingly suppressed subsequent flower bud formation of the fruiting upright. This result is further evidence for the existence in flowers or developing fruits of an inhibitor of floral induction (Eaton, 1978), as has been found in other fruit crops (Buban and Faust, 1982).

'Ben Lear' differed the most in \%RB among regions, from $16 \%$ in MA to $74 \%$ in WI (Table 1). The growing region also had

Table 1. Percent return bloom and fruit in 1990 for uprights of cranberry cultivars grown in various states.

\begin{tabular}{lccc}
\hline \hline Cultivar & State & $\begin{array}{c}\text { Return bloom } \\
(\%)\end{array}$ & $\begin{array}{c}\text { Return fruit } \\
(\%)\end{array}$ \\
\hline Stevens & MA & $27 \mathrm{a}^{\mathrm{y}}$ & $24 \mathrm{a}$ \\
& WI & $53 \mathrm{~b}$ & $46 \mathrm{~b}$ \\
& NJ & $59 \mathrm{~b}$ & $53 \mathrm{~b}$ \\
& OR & $32 \mathrm{a}$ & $26 \mathrm{a}$ \\
Ben Lear & MA & $16 \mathrm{a}$ & $15 \mathrm{a}$ \\
& WI & $74 \mathrm{~d}$ & $49 \mathrm{c}$ \\
& NJ & $26 \mathrm{~b}$ & $20 \mathrm{a}$ \\
& OR & $42 \mathrm{c}$ & $37 \mathrm{~b}$ \\
Crowley & MA & $28 \mathrm{a}$ & $26 \mathrm{ab}$ \\
& WI & $44 \mathrm{~b}$ & $37 \mathrm{~b}$ \\
& NJ & $44 \mathrm{~b}$ & $34 \mathrm{~b}$ \\
Early Black & MA & $28 \mathrm{a}$ & $19 \mathrm{a}$ \\
& NJ & 25 & 14 \\
Howes & MA & 24 & 22 \\
& NJ & 14 & 21 \\
Searles & WI & 45 & 13 \\
McFarlin & OR & 31 & 36 \\
\hline
\end{tabular}

${ }^{2}$ All uprights flowered in 1989; return fruit included all uprights with at least one viable fruit per upright.

${ }^{y}$ Mean separation within cultivar by a Waller test at $\mathrm{P}>0.05$. 


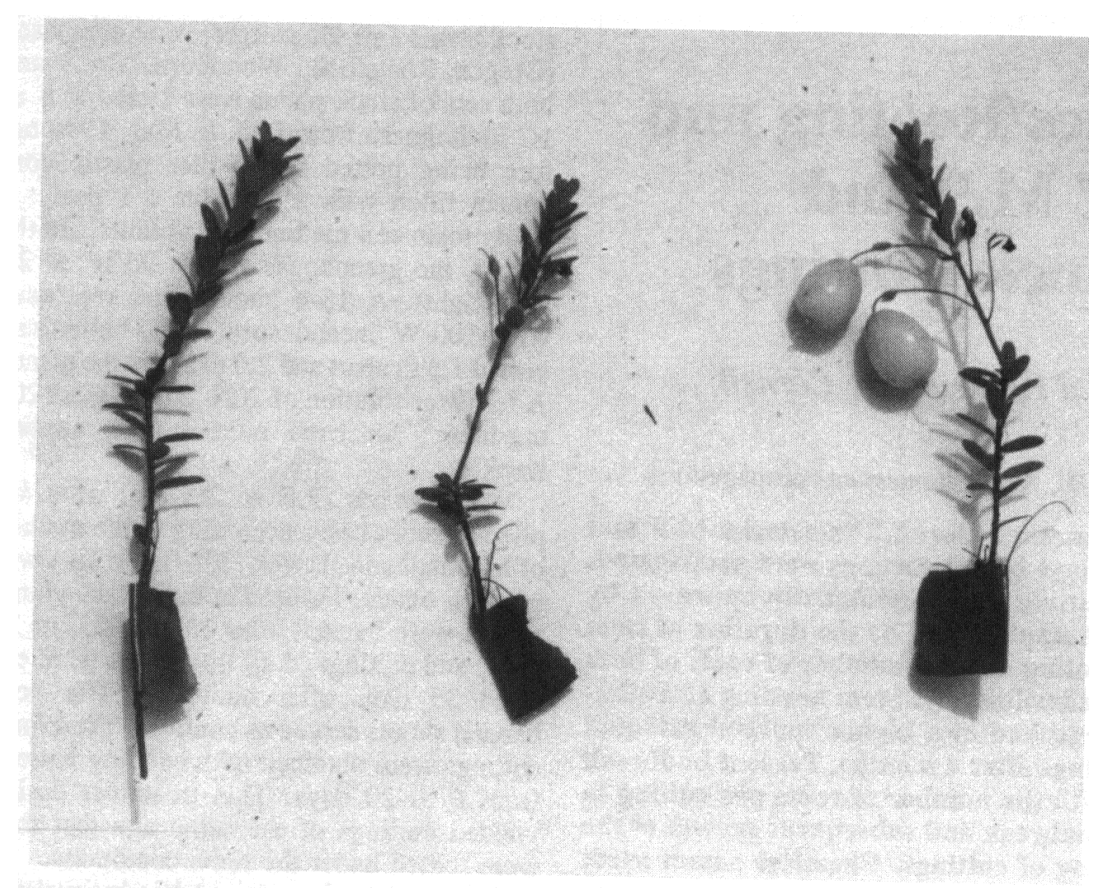

Fig. 1. 'Stevens' American cranberry. (left) Upright that flowered in 1989 but did not flower in 1990 (center) flowered in 1989 and 1990, but set fruit aborted; (right) flowered in 1989, flowered ad fruited in 1990 .

a significant effect on \%RB in 'Stevens' and 'Crowley'. With the exception of 'Ben Lear', cultivars tended to have a higher \%RB when grown in $\mathrm{WI}$ or $\mathrm{NJ}$ than when grown in MA or OR.

The differences in \% RB and \% RF among regions for a particular cultivar may be due to cultural or environmental factors. The age of the bed, yield in 1989 and 1990, and cultural practices, such as sanding, pruning, and fertilizer usage, differed among regions and cultivars. For example, yield in 1990 for 'Stevens', 'Ben Lear', and 'Crowley' ranged from 17 to 34,23 to 25 , and 7 to $22 \mathrm{t} \cdot \mathrm{ha}^{-1}$, respectively. Roberts and Struckmeyer (1942) showed that \% RB was affected by bed vigor or OR; however, cultivars in these regions did differ in \%RF. Cultivars grown in WI did not differ in \%RF.

In previous reports, researchers did not distinguish between uprights with return bloom that set or did not set fruit. If the development of fruit on an upright can limit floral induction for the following year, there may also be a threshold where there is sufficient energy for floral induction, but the resulting flowers are weak and, thus, less likely to set fruit.

Cultivars differed in \% RB and set within and among regions. Regional differences for a particular cultivar could result from cultural or environmental effects. The low \% RB for most cultivars could be due to resource limitation or hormonal factors during fruiting, adversely affecting concurrent flower bud initiation and \% RB the following year on these particular uprights. Cultivar and regional or cultural management responses could ultimately be determined by differences in photosynthetic efficiency and partitioning of photosynthates. The physiology of either function has-yet to be determined in cranberry.

\section{Literature Cited}

Baumann, T.E. and G.W. Eaton. 1986. Competition among berries on the cranberry upright. J. Amer. Soc. Hort. Sci. 111:869-872.

Buban, T. and M. Faust. 1982. Flower bud induction in apple trees: Internal control and differentiation. Hort. Rev. 4:174-203.

Eaton, G.W. 1978. Floral induction and biennial bearing in the cranberry. Fruit Var. J. 32:5860.

1942). Thus, vigor, which can be affected by many cultural practices and the environment, plays a role in $\% \mathrm{RB}$.

Despite the high \%RB for some cultivars in a particular region, many flowers did not set viable fruit. In 'Ben Lear', for example, $\mathrm{RF}$ in WI was only $49 \%$ when RB was $74 \%$, and in NJ, it was $20 \%$ when RB was $26 \%$ (Table 1). There was no significant difference in \%RB among cultivars grown in MA
Eck, P. 1990. The american cranberry. Rutgers Univ. Press, New Brunswick, N.J.

Lenhardt, P.J. and G.W. Eaton. 1977. Cranberry flower bud initiation in British Columbia. Fruit Var. J. 31:44.

Roberts, R.H. and B.E. Struckmeyer. 1942. Growth and fruiting of the cranberry. Proc. Amer. Soc. Hort. Sci. 40:373-379. 